\title{
Names, Bodies and Identities
}

\section{Abstract}

In this article, I argue that the emerging field of the sociology of naming should recognize the fundamental importance of bodies in the range of social practices through which individuals come to have, and to be identified by, names. I introduce the concept of 'embodied named identity' to describe the outcome of identificatory practices of naming fundamentally orientated around and rooted in the body. I argue that the concept addresses the neglect of the body within the sociology of names and the neglect of naming within both the sociology of identity and in the sociology of the body. In my elaboration of the value of the concept of embodied named identity for enhancing sociological understanding, I focus on evidence on naming practices in relation to sexed and gendered bodies, racialized and ethnic bodies, bodies, nicknames and characterisation, 'nameless' bodies and 'body-less' names.

Key words: names, naming practices, identity, the body, embodied named identity Jane Pilcher, Department of Sociology, University of Leicester

Corresponding author details: Jane Pilcher, Department of Sociology, University of Leicester, University Road, Leicester, LE1 7RH, UK. Email: jlp3@le.ac.uk

My name is printed at the head of this article, identifying me as its author. My name identifies me in other ways, too. My forename indicates my sex and gender and my surname displays my family affiliation. My forename-plus-surname also suggests other aspects of my identity, such as my ethnicity, and even my cohort-age and social class. My name was officially registered by my parents shortly after my birth, in adherence with legal and civil administrative requirements: under the UK's 1953 Births and Deaths Registration Act, newborn babies must be registered with both a forename and surname within 42 days of birth. Subsequently, my name has become what I am 'known by'. I think of me as 'Jane Pilcher'. Family members, friends, colleagues and acquaintances, and people in organizations and institutions, know and/or identify me, or administratively process me, as 'Jane Pilcher'. My name is used, by myself and others, routinely and repeatedly in my everyday life - in conversations and in written communications in a multitude of contexts. 
My name appears on numerous cultural artefacts that record and authenticate identity in the UK, including my birth certificate, my workplace ID card, my passport and my utility bills.

As my own case suggests, the names we have are at the nucleus of our individual identity and of our family affiliation, as well as our social and civil-legal identities (Finch 2008). Yet, despite the fundamental, ubiquitous and ongoing importance of names in everyday life, the sociology of names remains in its infancy. The most significant body of existing sociological work is comprised of studies of names in terms of displaying or constituting family affiliation or identification (for example, in the UK, Almack, 2005; Davies, 2011; Edwards and Caballero, 2008; Finch, 2008; Thwaites, 2013; Wilson, 2009). As Finch (2008: 710) points out, a more fully developed sociology of naming is potentially wide in scope: it is not my intention to detail it here. Rather, my aim in this article is to contribute to the emerging field of the sociology of naming by focusing on a hitherto neglected aspect: the relationship between names, identity and the body.

\section{Names, identity and the body: a neglected relationship}

The relationship between names, identities and the body has largely been taken-for-granted by sociologists. For example, early discussions of naming by Althusser (1971) and by Elias (1991) recognised the relationship between naming and identity, but overlooked the body. Althusser briefly discussed surnames in the context of the 'familial ideological configuration' (1971: 176); he also noted how names are one of the 'practical rituals' of everyday life which routinely allow us to recognise ourselves and others as unique individual subjects (1971: 173). In turn, Elias briefly mentioned names in his essay on 'I-We' identities first published in 1987 (Elias 1991). For Elias, forenames help denote individuality (or 'I' 
identities), whilst surnames are clearly important in signalling 'We' identities ('we are family'). For both Elias (1991) and Althusser (1971), then, as for Finch (2008), forenamesplus-surnames serve to mark out (unique) individuality as well as (family) connectedness but the relationship between names, identities and bodies is left unexamined in these accounts. In analyses of identity (for example, Jenkins, 2008; Lawler, 2008), and of the body (for example, Howson, 2004; Shilling 2008, 2012), the inextricable relationship between the body and identity is emphasised. As Jenkins (2008: 41) writes 'identification in isolation from embodiment is unimaginable'. Likewise, Shilling (2008: 169) argues that 'whilst the properties of the body may not determine individual identity, they are irreducibly important to the ongoing construction of it'. However, in these discussions of embodiment and identity, the relationship between the body, identity and naming is overlooked: names are discussed as asides, or not at all. Likewise, ethnomethodological perspectives may argue for people's sense-making through the use of interpretive and categorising tools, but the key part played by personal names in attributing individual and social identity has been largely overlooked. For example, in classic analyses by Garfinkel (1967), Kessler and McKenna (1978) and West and Zimmerman (1987), the role of names in displaying, determining and attributing gender identity is glossed over. Similarly, whilst the interpretivist approach of labelling theory (for example, Becker 1973) can be taken to suggest that names (as a type of label) can motivate individuals to behave in ways appropriate to that label, its focus on labels in relation to societal reactions to deviancy has meant that the specific role played by personal names in identification practices has been neglected.

In contrast, Erving Goffman did directly (if not expansively) address the relationship between identity, bodies and names as part of his exploration of how identity is established 
through interaction in particular locales. For Goffman, names are an example of an 'identity peg' (1968: 76), and as such contribute to the interactive (and embodied) performance and display of individual and social identity (including gender and ethnicity) in social settings (1976: 76; 1968: 76, 79). For Goffman, the 'complexes of information' about an individual that makes them identifiable as such are, more often than not, "bound both to name and body' (1968: 74). As Howson (2004: 12) states in relation to identity, 'we are bodies' in that we experience, understand and interact with the world from our bodies, and others 'see', interpret and interact with us via our bodies. However, drawing on Goffman's $(1968,1976)$ insights, it is my argument in this article that embodiment and identity are also inextricably intertwined with naming: above all else, forenames and surnames effectively 'label' or identify an individual's body. Contrary to Althusser (1971), Elias (1991) and Finch (2008), on their own forenames-plus-surnames (let alone just forenames or just surnames) do not, in fact, mark individuals out as unique. My forename-plus-surname 'Jane Pilcher' is not an effective identifier of me as a unique individual. My forename is common, my surname less so. Yet, there are numerous other girls/women with the name 'Jane Pilcher', both historically and contemporarily. The uniqueness of my identity, my individuality, arises instead from the coincidence of my forename-plus-surname as a label applied to my face and body as the visible, tangible and distinctive surfaces of myself. Hence the importance given to passports and other 'identity documents' (Goffman 1968: 78) where authenticity of identity is arrived at through the verified matching of names with bodily appearance. Our individual, social, civil and legal identities are, then, produced by the intertwining of our forenames and surnames with our bodies. Identities arise out of the complex meshing of the connections between names, bodies and identity that I subsequently refer to as the 'namesbodies-identity nexus'. My aim in this article is to direct sociological attention to the 
indispensable importance of naming as an identificatory practice, and to the various ways the body is fundamentally important in naming as an identificatory practice. To do this, I draw from the small pool of sociological empirical studies on naming, along with examples from literature, popular culture and current affairs to fill in gaps in sociological coverage. I argue that sociologists need to recognise and deploy the concept of 'embodied named identity' as a tool useful in exploring and explaining the relationship between names, bodies and identities. The concept portrays the individual and social identity of a person as resulting from the enactment, both within and beyond family settings, of a cluster of identificatory social practices of naming that are fundamentally orientated around and rooted in the body. In developing the case for the concept of embodied named identity as a useful addition to the sociological toolkit, I begin by describing the legal and cultural context framing naming practices in the UK, which points to the centrality of forenames and surnames to experiences of contemporary personhood, identity and citizenship. The main part of my article illustrates the various ways in which bodies are irreducibly important in naming as an identificatory practice. I focus on evidence on naming practices in relation to sexed and gendered bodies, racialized and ethnic bodies, bodies, nicknames and characterisation, 'nameless' bodies and 'body-less' names. This (deliberately wide) range of examples together detail the practices and processes that result in embodied named identities: what these practices are and how they are done, and by whom, and what their spatial and temporal contexts are. The final section of the article focuses on embodied named identity as a concept, elaborating on its features and reflecting upon its usefulness in illuminating the relationship between names, identities and the body. 


\section{Names in the UK: Legal and Cultural Contexts}

In the UK, individuals are required by law to have to have at least a forename and a surname. Whilst forenames allow for individuality, surnames 'root the individual in a kin network' (Finch, 2008: 712). Surnaming practices in the UK are governed by patrilineal and patronymic cultural rules: at marriage it is routine that women change from their birth surname to that of their husband, and that children are surnamed after their father. 'Fixed' names that persist over time (especially for men) and family surname choices favouring the retention of men's family surnames from generation to generation are argued by historians to be linked to the development in the UK of private property rights, modern legal systems and the expansion of the modern nation-state and its role in administering and governing its citizens as unique individuals (Scott et al, 2002), albeit gendered ones (Marshall, 1994; Pateman, 1988).

In addition to the requirements of the 1953 Births and Deaths Registration Act noted earlier, there are restrictions in the UK (under the 1989 Children's Act) on changing children's surnames subject to the consent of those adults deemed to have parental responsibility for them. Otherwise, the contemporary UK legislative framework regulating names is permissive. To some extent, the laissez faire quality of the legislative framework undermines the state's requirement for names that are 'fixed' and for identities that are traceable, administrable and governable. In fact, under English common law, an adult person may take and use any name, perfectly legally, without drawing up any formal record, provided that such action is not undertaken for the purpose of fraud. If a formal record of name changing is required individuals can use the Deed Poll Service (or similar procedure) to change officially any part, or all, of their name, including forename and surname, an 
unlimited amount of times and for any reason, provided it is not for deceptive or fraudulent purposes. Under UK law, then, adult individuals can freely choose the names (forename and surname) that they wish to be 'known by'. Despite this permissive legal framework, only a minority of people (c. 60,000 in 2011) in the UK use the Deed Poll Service to make official changes to their forenames or surnames (The Guardian, 2011). Unknowable numbers of others may, however, use a range of names on an 'unofficial' basis. The major group of official name changers using the Deed Poll Service in 2011 were women changing their surnames after a divorce, followed by ethnic minorities choosing 'Anglicised' names in order to avoid racial discrimination and prejudice, in job applications for example (Legal Deed Poll Service, 2010). These findings in themselves are suggestive of the relationship between names, bodies and identities; I will elaborate on their significance later.

In theory, then, naming practices in the UK are relatively unfettered by legislation. However, the enactment of law, policy and administrative procedures, and on-going 'speech acts' (Austin, 1962) makes naming a rather more constraining experience in practice. From the initial speech act and practices of naming a new-born in adherence with legal and civil administrative requirements and cultural norms, a ripple effect spreads out: 'given' names become more fixed as the named individual becomes ever more socially and culturally incorporated, and legally and socially administered as a citizen. Having a formal forename and surname that is (more or less) consistent across time and variable contexts, and that is authenticated by 'identity documents' (Goffman 1968) like birth certificates and passports and verified by the ongoing speech acts of others, remains core to experiences of contemporary personhood, identity and citizenship in the UK. Next, I show how bodies are 
fundamentally important in the range of social practices by which individuals come to have and be identified by names, beginning with the example of sexed and gendered bodies.

\section{Naming the sexed and gendered body}

The relationship between sexed and gendered bodies and names represents the most obvious example of the cluster of social practices which result in embodied named identity. It is the cultural norm in the UK (as elsewhere) to give babies a 'sex-specific' forename, according to the categorisation of the body (on the basis of its genitalia) as a 'male' or a 'female'. Androgynous forenames are rarely used (Lieberson, Dumais and Bauman 2000). Drawing on Connell's $(1987,2009)$ approach, I argue that we can recognise sexed and gendered naming both as a tool of categorisation and a tool of negation, which interact to 'help shape the bodies of women and men in ways that reinforce particular images of femininity and masculinity' (Shilling, 2012: 108). Once the body of a new-born individual has been 'forenamed' by others, based on the interpretation that has been made of its sex, then a whole host of other negating cultural practices also begin to be enacted to construct and reinforce feminine or masculine embodied identity. These range from, for example, colourcoded celebratory balloons and flowers at birth, to gender-appropriate clothing and toys in childhood, and as I discuss shortly, adult women 'giving up' their birth surname at marriage in order to 'take' the surname of their husband. Names, I argue, are a core part of what Shilling (2008: 76) calls the 'body pedagogies' of appearances, activities, skills and capacities which cumulatively construct embodied femininities and masculinities, along with other social identities. 
The relationship between names and sexed and gendered bodies can be further illuminated by examples from popular culture. The song 'A Boy Named Sue', made famous by Johnny Cash, is suggestive of what can happen when 'contradictory embodiment' (Connell, 2009) occurs: in this case, when normative expectations about the coincidence of sex, gender, bodies and forenames are breached. The song tells the tale of an individual who was at birth declared to be a boy, but was given the (feminine) forename 'Sue' by his soon-to-be absent father. As a consequence of his 'girl's' name, Sue was ridiculed and 'grew up quick and grew up mean'. His name sculpted his body, as his 'fist got hard' from fighting. Years later, Sue finds (and fights with) his father over his forename. His father explained that he had deliberately chosen a girl's name ('Sue') to help his son 'get tough' and be 'strong' in his absence. Here, then, a feminine name bestowed on a male body is portrayed as a creative and strategic choice to help produce a hyper-masculine body and character. In a similar situation, the writer and broadcaster Clive James opted to change from his given forename, Vivien, which is widely regarded in English-speaking cultures as a 'girl's' name (McCrum, 2013).

A realignment of forenames with embodied identity is also evident in the efforts of transpeople to 'pass', by changing their birth forename to a sex-specific one that is appropriate to their chosen gender. Examples here include Garfinkel's (1967) 'Agnes' (although Garfinkel in fact fails to analyse names in relation to Agnes) and Chelsea Elizabeth Manning, formerly Bradley Manning, a US soldier jailed in 2013 for leaking classified documents (Gabbatt, 2013). For transpeople, names are obviously intertwined with embodiment, as is also the case for individuals whose forename either 'contradicts' their embodied sex or gender (as in 'A Boy Named Sue', or the UK food writer Jack Monroe, 
whose blog and book are entitled 'A Girl Named Jack') or whose forename is 'genderneutral' (e.g. 'Taylor' or 'Jamie'). In such cases, individuals are likely to have to deal with the consequences arising from their forenames failure to 'accurately' or 'clearly' declare and display their sex and gender.

As the examples of Clive James, 'Agnes' and Chelsea Manning suggest, the connections between names, identification and the sexed and gendered body are not fixed, inseparable or unchanging. Moreover, as I noted earlier, names do not operate in the same way for heterosexual women and men in the UK in relation to embodied identity. Patronymic surnaming practices mean that the relationship between names, bodies and identification is less secure and more flexible for women over the life course than it is for men. According to a survey conducted in $1995,94 \%$ of married women in the UK change their surname to that of their husband (Valetas, 2001). Moreover, as noted earlier, the major group of 'official' name changers using the Deed Poll Service in the UK are women reverting back to their birth surnames after divorce (Legal Deed Poll Service, 2010). At marriage and at divorce, heterosexual women's bodies routinely become objects of intensive social practices of (re)naming, by embodied agents who name: for example, by women themselves, by family and friends and by religious, civil, legal and administrative officials. The taken-for-granted quality of patronymic surnaming practices can be illustrated by my own experience, which also reveals the ways sexed and gendered bodies are objects of social practices of naming. My male partner and I had a civil marriage ceremony in 2007. At the point of signing the marriage register, the Registrar reminded me (presumably having categorised me on the basis of my bodily appearance as the woman in our heterosexual partnership) not to sign it using my 'new' married name, but in my 'old' surname. The Registrar (whose role requires 
them to be impartial and neutral) made the (erroneous) assumption that $\mathrm{I}$, as a

heterosexual woman, would change my surname as an automatic consequence of marrying.

What lays behind contemporary patronymic surnaming practices and what do they indicate about embodied named identities? Evidence from a comparative study of US and Russian women suggests that women change their surnames at marriage for reasons of family connectedness (to show marital union and commitment, family solidarity, to signify the beginning of a new stage of life) or pragmatism, as a means of avoiding confusion over disparate surnames within a family unit (Boxer and Gritsenko, 2005. See also Thwaites, 2013; Wilson, 2009). These findings support arguments by scholars that surname choices are linked to family practices of the display of connectedness and affinities (Almack, 2005; Davies, 2011; Finch, 2008). Of course, amongst heterosexual married couples, such outcomes of surname changing could equally be achieved by men changing their surnames and relinquishing their prior embodied named identity. Yet, the evidence is that men are not expected to do so and very few men actually do. There are no available UK figures for how many men change their surname to that of their wife, but, in contrast to women's experiences, it remains a very rare and less than straightforward process. A newspaper report by Harris (2008) reveals how difficult it is for a man to change his surname to his wife's at marriage (men have to use the Deed Poll Service or similar procedure) and how people respond with confusion, disbelief and disapproval if he does. Patronymic surnaming practices, then, must be recognised as crucial to the constitution and display of embodied gender identities and relationships, as well as to family and kinship relationships. The importance of patronymic (and patrilineal) naming practices for embodied gender identities is further indicated by the gender divide between women and men on the issue of 
surnaming. In essence, evidence suggests that men are much more likely than women to favour the retention of conventional patronymic and patrilineal surnaming practices (in the US, Intons-Peterson and Crawford, 1985 and Scheuble and Johnson, 1993; in the UK, Wilson, 2009). In a UK study, Thwaites (2013) found that some men became very upset if their woman partner even considered the idea of not changing their surname at marriage. These findings suggest an association, amongst some men at least, between patronymic, patrilineal surnaming practices and the constitution and display of masculine heterosexual embodied identity.

\section{Names, bodies and ethnic and racialized identities}

Identificatory practices of naming, through both forenames and surnames, are also related in important ways to the embodiment of ethnic and racialized identities. I noted in my introduction that my name 'Jane Pilcher' is at least suggestive of my ethnicity - white, English-speaking (Fryer and Levitt 2003). As Khosravi (2012: 65) argues, 'Names carry strong ethnic and religious connotations and reveal an individual's affiliation to a specific group'. My argument here is that names are also a core part of the 'body pedagogies' (Shilling, 2008) which together construct embodied racialized and ethnic identities, with a range of both negative and positive consequences in terms of identificatory experiences and affiliations.

In a review of evidence on the links between names, ethnicity and inequality, Edwards and Caballero (2008) argue that, although some studies in the US propose that distinctively African-American personal names (such as 'Shanice' or 'DeShawn') or 'low status' names lead teachers to have less expectations of children's attainment, and thus to lower 
educational outcomes (Figlio, 2005), others find no such association between 'Black' names and life outcomes. Fryer and Levitt (2003), for example, concluded that, rather than names, it is the socio-economic circumstances in which children are born and raised that are primary in shaping life outcomes. Links between surnames, ethnicity and life outcomes in relation to job opportunities and employment have also been addressed (for example, Rubinstein and Brenner, 2014; Widner and Chicoine, 2011). In the UK, a study for the Department of Work and Pensions (Wood et al, 2009) tested for racial discrimination in recruitment practices by sending out sets of equivalent applications to job vacancies across the UK, using names commonly associated with minority groups. The level of name-based racial discrimination was found to be high across all ethnic groups, even discounting differences such as age and education. Specifically, in order to secure a job interview, 74\% more applications from candidates with ethnic minority names had to be sent out compared to candidates with 'white' names. This finding helps contextualise the fact (noted earlier) that the second largest group of official names changers using the UK's Deed Poll Service is ethnic minority individuals seeking to 'Anglicise' their names. There is a long history of immigrants changing their surnames to make them more like those which predominate in the host country, thereby reducing their 'difference'. This naming practice continues in the twenty-first century, as shown by Bursell's (2012) examination of name changing amongst minority ethnic individuals in Sweden (see also Khosravi, 2012). In changing their names, Bursell argues, immigrants 'seek not only economic mobility, but also recognition as an equal human being' (2012: 484). Other evidence points to the more positive links between embodied ethnic or racialized identity and names. In the UK, a study by Edwards and Caballero (2008) focused on practices of the forenaming of children by couples with 'mixed' ethnic and faith backgrounds. In the case of 'mixed' couple parents, it was found that 
children's forenames, core to their individuality, were in part chosen to 'symbolise' a shared, collective ethnic or religious heritage. I suggest that Edwards and Caballero's findings can be recast to argue that, through children's forenames, collective ethnic, racial or faith identity is embodied in subsequent generations (see also Elan, 2014). Likewise, in a US study, Fryer and Levitt (2003) argued that 'Black' names may have localised benefits in denoting ethnic or racial solidarity.

The evidence I have presented here shows that names carry strong connotations of embodied, often racialized, identity. Ethnic and racialized bodies are important in the range of social practices by which individuals come to have and be identified by names. So much so, that, for example, a dissonance might be experienced if names are 'seen' not to match ethnic or racialized bodily appearance and/or nationality. Sarah Ahmed, a British sociologist, describes her experiences at US border controls of the consequences of what Connell (2009) has called (albeit in a different context) 'contradictory embodiment'. Ahmed (2007: 162) recounts that 'the name Ahmed slows me down' because it made her the focus of especial attention by border control staff. This is because her name was perceived as a Muslim name, and therefore marked out her bodily self as, if not potentially dangerous, then at least out of place. As Ahmed concludes, having 'the right [British] passport makes no difference if you have the wrong body or name' (2007: 162. See also Osman, 2014; Wykes, 2015). In other words, that key artefacts of identification, even the passport, can be undermined by a perceived dissonance or 'contradiction' between the bodies we see and the names and nationalities stereotypically or prejudicially attached to them reveals the intertwining of the names-body-identity nexus. Evidence on the relationship between 
names, identification and racialized and ethnic bodies again shows the usefulness of conceptualising our individual and social identities as 'embodied named' ones.

\section{Well-named? Nicknames, characterisation and the body}

Earlier I argued that despite permissive legislative framework (in the UK at least), usage, replication and temporality combine to make 'given' names rather more fixed and 'sticky' to our bodies in practice than in theory. In contrast, nicknaming is more informal, creative and flexible. The use of nicknames can be a sign of affection, closeness or familiarity, of belonging to a group. Less positively, nicknames can be used to ridicule or abuse an individual, thereby connoting an 'outsider' status to the nicknamed. Nicknames come in a variety of types; my focus here is nicknames in relation to the body. There is a long tradition of nicknaming people through reference to their body: for example, 'Little John' in the tales of Robin Hood. Other well-known examples include Four Eyes, Titch, Ginger, Paki, and Fatso. In each case, the nickname derives from the highlighting of a particular aspect of the embodied identity of the person - their wearing of glasses, their diminutive statue, the colour of their hair, their racialized ethnicity or their body shape - and act, in some contexts and across some social networks, in place of 'given names' to identify that person. Nicknaming practices that accentuate an aspect of a person's body mean that the person's informal name (their nickname) embodies their identity, in a clearly visible way. Drawing on the analysis of Hockey and James (1993) in relation to the ways 'wrinkly' is used in relation to old people, these kind of nicknames represent the use of adjectives (describing words) as nouns (naming words). Although, as in the case of 'wrinkly', body-related nicknames can be deployed a derogatory way, they can also at times be inverted or re-appropriated by the nicknamed as a source of resistance and empowerment. 
There is a similarity between the way nicknaming practices draw on the names-bodiesidentity nexus and commonplace associations between names and embodied character traits or personality (it is here, perhaps, that insights suggested by labelling theory have potential for understanding practices of embodied named identity). Examples of such nicknames might include 'Plain Jane', 'Steadfast John', 'Lively Genevieve' and 'Thuggish Buster'. Scriptwriters and novelists are especially adept at using associations between names and embodied character or personality traits. Of course, associations made between names and identities in terms of embodied character traits or personalities are intangible and impossible to substantiate. Irrational, inexplicable and evanescent they may be, but the association made between some names and fleshy, embodied identities may well speak to some (real) people's sense of (dis)association from their 'given' name. Other people, too, might argue that someone's given name does/doesn't 'suit them' in some way, in terms of their embodiment: 'He doesn't look like a Harold' or 'Serena is well-named'. As I discussed earlier, disassociation from a given name may also occur when a person's racialized ethnic embodied identity or their gendered embodied identity is interpreted (by others or by themselves) as not 'matching' their name.

Nicknaming practices are informal, are often highly context and social network dependent and can depend heavily on subjective interpretations made of an individual's bodily or character traits. As revealing as they are about the names-body-identity nexus, such features mean that nicknames and characterisation have limited robustness, longevity and validity compared to the embodied named identity which results from the conjunction of bodies with forenames and surnames. Next, in elaboration of the importance of the more 
'formal' names-body-identity nexus, I consider the difficulties that can arise if forenames and surnames get separated from 'their' bodies.

\section{Identity problems: nameless bodies and body-less names}

I have left until last the examples of 'nameless bodies' and 'body-less names' because, in revealing the problems arising from the separation of formal/legal names from bodies, the fundamental importance of the relationship between names, bodies and identity is emphatically demonstrated. A case in point is the generic identifier 'Jane/John Doe'. Unidentified bodies are commonly labelled with the name of 'Jane Doe' (for female cadavers) or 'John Doe' (for male cadavers). In such cases, the body is unidentified precisely because its formal forename-plus-surname is unknown. A Jane or John Doe can be 'identified' in other ways - its sex and 'race', hair colour, height, weight and the scars, birthmarks or tattoos it might bear. Yet, without a name, detailed on an accompanying cultural artefact like a driver's license, credit card or other 'identity' source, or as revealed by a person who has been asked to 'identify' (name) it, the body remains 'unidentified'. Biomarkers of identity, such as fingerprints, retina scans, dental records or DNA, or CCTV footage, remain of limited use for identification purposes if links to a name cannot be made.

Another way bodies can become nameless is when an individual's name is taken away as an expression of power and control. As Finch (2008: 712) notes, anthropological literature on slavery points to the control of the powerful over the naming of the powerless. Likewise, in institutions like prisons and concentration camps, a strategy for dehumanising and deindividualising inmates is to take away their name and replace it with a number. Thus, on Robben Island, anti-apartheid activist Nelson Mandela became prisoner '46664' and in 
Auschwitz, the Jewish Italian author and scientist Primo Levi became '174517'. In the case of many prisoners in Auschwitz, their number literally became part of their embodied identity via it being tattooed on their arms or other parts of the body. Even in such cases, though, the embodied-numbered identity remains traceable back to a name recorded in administrative records (Eddy 2007). Without some administrative record or biometric sample linked to a name, individual identity cannot be established. The discovery of King Richard III under a car park in Leicester, England, is a further case in point. In order to establish the identity of the skeleton discovered in the archaeological dig, a living descendant of the King was traced through a genealogical investigation, using surnames and family lineage and, in a genetic investigation, DNA. In other words, both names and embodied identity (in the form of DNA) were crucial in the process of authenticating the identity of the skeleton as King Richard III (University of Leicester 2014).

The example of 'body-less names' also illuminates the close meshing of the relationship between names, bodies and identity, and the problems of identification that arise if one element is missing or hidden. In some respects, online identities, where individuals have a 'user name', amount to 'disembodied' identities. It is this feature which (for example) allows paedophiles to pose as someone younger or of another gender in order to access children they have a sexual interest in. The disembodiment made possible by online identities may also help account for internet trolling, where, behind a cloak of anonymity afforded by a username, some individuals feel free to be abusive and threatening to others. There are, of course, much bigger debates about corporeality and cyberspace that it is unnecessary to rehearse here (see, for example, Murray and Sixsmith 1999; Schultze 2014). The point I wish to make is that, although user names act as a pseudonym and therefore engender a sense of 
anonymity which may encourage abusive and criminal behaviour in or through cyberspace, ultimately they are not disembodied identities: user names, IP addresses and so on are traceable back to an embodied person through their 'real' names. Hence, paedophiles posing as teenagers are traced, prosecuted and incarcerated and internet trolls are likewise traced, with penalties if found guilty. In short, online identities in the form of user names are not, in the end, 'body-less' identities or disembodied names. Another type of 'body-less names' may be those arising from 'false' identities set up by fraudsters, or state intelligence agencies. In identity theft, as noted above, a real person's name and related personal details are 'stolen' from the embodied person to which they legally belong. In identity fraud, names and other related personal details are used to set up a paper or electronic trail to administratively create a person who is not 'real'. Yet, as anyone who has ever watched 'The Bourne Identity' or similar movies knows, the strongest authentication of 'false' identities requires some kind of 'photo ID'. As represented by Hollywood at least, undercover intelligence personnel like Jason Bourne have multiple passports in multiple names: the (same) body is depicted in those passports, albeit associated with various (false) names. Even in cases of identity theft, identity fraud and deception, then, connections between identity, bodies and names have to be addressed and managed. Detection of identity theft and identity fraud involves, in the former case, establishing to whose body the stolen name and related personal details 'really' belongs, and in the latter case, that there is no real embodied person with that name and related personal details in existence. Identity crimes and their detection show once again that the names-body-identity nexus is core to practices that constitute and identify individual persons. 


\section{Embodied-named identity: features and utility}

Some sociologists (e.g. Althusser 1971; Elias 1991) have noted links between names and identity, whilst others (e.g. Jenkins 2008; Shilling 2008) have focused on identity and the body. It is interactionists (especially Goffman) who have come closest to addressing directly the otherwise overlooked relationship between names, bodies and identities. In the face of this neglect of the names-bodies-identity nexus, my purpose here has been to illuminate the indispensable importance of naming as an identificatory practice and to make visible to sociologists the key ways the body is imbued in naming practices. Through the examples of sexed and gendered bodies, racialized and ethnic bodies, nicknames and characterisation, name-less bodies and body-less names, I have illustrated practices which result in 'embodied named identity': that is, the individual and social identity of a person created and recreated through the ongoing and reciprocal (re)enactment, both within and beyond family settings, of a cluster of identificatory social practices of naming that are fundamentally orientated around and rooted in the body. By way of a conclusion, I focus on the concept of embodied named identity, elaborating its features and reflecting upon its utility.

To paraphrase Finch's (2007: 79) reflections upon her own concept of 'display', my concept of 'embodied-named identity' provides a way of understanding phenomena evident in everyday experiences and described in empirical studies but hitherto overlooked by sociologists. For me, the concept of embodied named identity is necessary because existing concepts such as 'identity' or 'embodied identity' do not adequately capture or help us better understand the kinds of practices and experiences of the names-body-identity nexus that have been the focus of this article, including the intangible characterisations and the 
corporeal fleshiness of names, and the social consequentiality of names in the contexts of power structures of gender and ethnicity. The concept of embodied named identity, I argue, enhances sociological analyses of the significance of names, and of the relationship between bodies and names in identificatory practices through which people define and recognise both themselves and others. It encapsulates Goffman's (1968) under-elaborated but tantalizing insight that the 'complexes of information' delineating individual and social identities are bound, invariably and inseparably, both to names and bodies. The complex meshing of connections made in and through interactive practices in relation to bodies and names are, I argue, important for individual and social identities, both formal and informal, and are key to ways in which 'the object-body is actively experienced, produced and/or sustained as a subject-body' (Waskul and Vannini, 2012: 3).

As illustrated through the various examples presented in this article, the concept of embodied named identity portrays bodies as the objects of ongoing and reciprocal social practices of naming, undertaken by embodied agents (for example, parents, friends, administrators, officials and potential employers) who, through 'speech acts', 'performative sentences' (Austin 1962) and cultural artefacts or identity documents, name, and are, in turn, named. Practices of embodied named identity draw upon culturally specific mutual knowledge and taken-for-granted understandings about names and bodies and take place in a range of institutional and organizational contexts, such as families, workplaces, border controls, Registry Offices, and criminal justice systems. As I have shown in this article, naming practices are processually-used tools of identification, categorisation and negation which contribute to the shaping of bodies in ways that produce and reproduce ideas about ethnic and racialized identities, sexed and gendered identities as well as more 'intangible 
affinities' (Mason, 2008), in relation to names, such as cohort-age, social class, character and personality traits. Practices of embodied named identity can be habitual and regularised (as in the case of the sex and gender specific naming of new-borns, for example), but they can also be purposeful, performative and contextually fluid (as in the case of transpeople or nicknames, for example). Choice, flexibility and creative invention in embodied named identity practices are evident in the use of pseudonyms, user-names and nicknames, in identity theft and identity fraud, as well as negotiations that might take place about whether or not a woman 'keeps' her birth surname at marriage, and which forenames and surnames children might be given (Almack 2005, Edwards and Caballero 2008). As discussed earlier, in the UK, women (at least heterosexual married ones) routinely change their surnames in line with traditions of patronymic naming, transgender people may change their names in order to 'pass', and ethnic minority individuals may change their names in order to better 'fit in' with the majority population, or to avoid prejudice and discrimination in employment. In reflection of their privileged social position, white men have the strongest, most consistent, embodied named identities over their life courses, and, conversely, are the least culturally enabled to make (official) changes to their names.

Alongside fluidity and choice, embodied named identities also have an element of fixity or non-electiveness to them. As discussed earlier, this is because our names come to us 'readymade', are chosen for our new-born selves by our parents, and subsequently become ever more 'sticky' to our embodied selves, through relational and situational use over historical time and through our social and cultural incorporation as individuals and citizens during our life course. Even if we do actively and purposively choose another (official, consistent) name for our bodily selves, it is likely that in official and/or administrative contexts (in the UK, at 
least), we will be asked to confirm whether or not we have ever used or been known by other names. Therefore, other (discarded, birth) names will always be 'there' in relation to our embodied selves and so remain the initial, and always present, reference point for identificatory practices. Fixity is also relevant to experiences of contradictory embodiment or dissonance in relation to names and bodies. As illustrated by 'A Boy Named Sue', by the experiences of transpeople or of individuals with an ethnic or racialized embodied identity that does not 'match' their name or nationality (Ahmed, 2007; Wykes 2015), there are strong cultural assumptions that names help 'fix' embodied identities, and vice versa. The concept of embodied named identity represents a challenge, then, to arguments that have been made about the potentialities of reflexive and flexible identities under conditions of late modernity (for example, Beck, 1992; Beck and Beck-Gernshiem, 2001; Giddens, 1991). In important ways, as I have argued in this article, our identities remain named embodied ones, shaped by habits, crises and creativity (to borrow Shilling's 2008 framework). Our names are both constituted by and help to constitute our sexed and gendered selves, our racialized and ethnic identities and other identifications that make us both a unique individual and a culturally embedded and socially administered citizen. In the contemporary techno-digital world, with ubiquitous practices of authentication and verification of identity, the rise of biometrics and of genetic fingerprinting, and of identity as the 'new money' (Birch, 2014), our formal embodied, named identities may become ever more complexly meshed with, and densely compressed into, one another.

Undoubtedly, there is scope for the further development of it, but the concept of embodied named identity I have introduced, illustrated and preliminarily elaborated on here does add to sociological knowledge of what Shilling calls 'body-subjects in their social contexts' (2008: 
5). It does so by making the body visible in practices of naming and by making visible the connections between naming and the embodiment of identity. To this extent, the concept has potential application beyond sociology, in fields of study such as criminology, genetics and genealogy, and even in relation to the management of identity theft and fraud, the use of biometrics and the practices of forensic science. Within sociology itself, the growing sociological interest in names is to be welcomed: naming practices, as quintessentially social processes, offer plentiful scope for developing a range of sociological understandings, not least of the balance between individuality and social connectedness, of practices of identification and of what Shilling (2008: 2) has called 'the social consequentiality' of corporeality and embodiment.

Acknowledgements: I would like to thank the anonymous reviewers of the earlier versions of this article for their constructive comments and suggestions. Colleagues at Leicester and elsewhere also aided the development of ideas and arguments I make in this article. It was written during a period of study leave granted by the University of Leicester.

\section{References}

Ahmed S (2007) A Phenomenology of Whiteness. Feminist Theory 8 (2): 149-168.

Almack K (2005) What's in a Name? The Significance of the Choice of Surnames Given to Children Born within Lesbian-Parent Families. Sexualities 8 (2): 239-254.

Austin J (1962) How to Do Things with Words. Oxford: Oxford University Press. Beck U (1992) The Risk Society. London: Sage. 
Beck U, Beck-Gernsheim E (2001) Individualization. London: Sage.

Becker H (1973) Outsiders, Glencoe: The Free Press.

Birch D (2014) Identity is the New Money. London: London Publishing Partnership.

Boxer D, Gritsenko E (2005) Women and Last Names Across Cultures: Reconstituting Identity in Marriage. Women and Language 28 (2): 1-11.

Bursell M (2012) Name Change and Destigmatization among Middle Eastern Immigrants in Sweden. Ethnic and Racial Studies 35 (3): 471-487.

Connell R (1987) Gender and Power, Cambridge: Polity.

Connell R (2009) Gender in World Perspective, Cambridge: Polity.

Davies H (2011) Sharing Surnames: Children, Family and Kinship. Sociology 45 (4): 554-561.

Eddy M (2007) Putting Holocaust Victims Names to Numbers'. USA Today, $2^{\text {nd }}$ October. Available at: http://usatoday30.usatoday.com/news/world/2007-02-10-holocaust_x.htm Edwards R, Caballero C (2008) What's in a Name? An exploration of the significance of personal naming of mixed children for parents from different racial, ethnic and faith backgrounds. Sociological Review 56 (1): 39-60.

Elias N (1991) The Society of Individuals. Oxford: Blackwell.

Figlio D (2005) Names, Expectations and the Black-White Test Score Gap. NBER Working Paper No. W11195, National Bureau of Economic Research: Cambridge MA.

Finch J (2007) Displaying Families. Sociology 41 (1): 65-81.

Finch J (2008) Naming Names: Kinship, Individuality and Personal Names. Sociology 42 (4): 709-725.

Fryer R, Levitt S (2003) The Causes and Consequences of Distinctively Black Names. NBER Working Paper 9938, National Bureau of Economic Research: Cambridge MA. 
Gabbatt A (2013) I am Chelsea Manning, says jailed soldier formerly known as Bradley. The Guardian, August 22nd.

Garfinkel H (1967) Studies in Ethnomethodology. Englewood Cliffs, NJ: Prentice-Hall.

Giddens A (1991) Modernity and Self-Identity. Cambridge: Polity.

Goffman E (1968) Stigma. Harmondsworth: Penguin.

Goffman E (1976) Gender Advertisements. Studies in the Anthropology of Visual

Communication 3: 69-154.

Harris S. (2008) No one understood why I took my wife's surname. The Independent. April 4th

Hockey J, James A (1993) Growing Up and Growing Old. London: Sage.

Howson A (2004) The Body in Society, Cambridge: Polity.

Intons-Peterson M J, Crawford J (1985) The meanings of marital surnames. Sex Roles 12

(11/12): 1163-71.

Jenkins R (2008) Social Identity, London: Routledge, $3^{\text {rd }}$ ed.

Kessler S, and McKenna W (1978) Gender: An Ethnomethodological Approach. New York: John Wiley \& Sons.

Khosravi S (2012) White Masks/Muslim Names: Immigrants and Name Changing in Sweden. Race and Class 53 (3): 65-80.

Lawler S (2008) Identity: Sociological Perspectives. Cambridge: Polity.

Lieberson S, Dumais S and Baumann S (2000) The Instability of Androgynous Names.

American Journal of Sociology 105 (5): 1249-1287.

Legal Deed Poll Service (2010) The Name Change Game. Available at

http://wwwthelegaldeedpollserviceorguk/

Marshall B (1994) Engendering Modernity. Cambridge: Polity. 
Mason J (2008) Tangible affinities and the real life fascination of kinship. Sociology 42 (1): 29-45.

McCrum R. (2013) 'Clive James - a life in writing', The Guardian, $6^{\text {th }}$ July.

Murray C Sixsmith, J (1999) The Corporeal Body in Virtual Reality. Ethos, 27 (3): 315-343.

Nugent C (2010) Children's Surnames, Moral Dilemmas: Accounting for the Predominance of Fathers Surnames Amongst Children. Gender \& Society, 24 (4): 499-525.

Osman J (2014) I am a British Citizen - Not a Second Class Citizen. The Guardian 26 May.

Pateman C (1988) The Sexual Contract. Cambridge: Polity.

Rubinstein Y, Brenner D (2014) Pride and Prejudice: Using Ethnic-Sounding Names and InterEthnic Marriages to Identify Labour Market Discrimination. Review of Economic Studies 81 (1): 389-425.

Schultze, U (2014) Performing Embodied Identity in Virtual Worlds. European Journal of Information Systems, 23 (1): 84-95.

Shilling C (2012) The Body and Social Theory, London: Sage, $3^{\text {rd }}$ ed.

Shilling C (2008) Changing Bodies. Habit, Crisis and Creativity, London: Sage.

Scheuble L, Johnson D (1993) Marital Name Change: Plans and Attitudes of College Students. Journal of Marriage and Family 55 (3): 747-754.

Scott J, Tehranian J and Mathias J (2002) The Production of Legal Identities Proper to States. Comparative Studies in Society and History 44 (1): 4-44.

The Guardian (2011) The boom in silly name changes. October $17^{\text {th }}$. Thwaites R (2013) The Making of Selfhood: naming decisions on marriage. Families, Relationships and Societies 2 (3): 425-439.

University of Leicester (2014) The Discovery of King Richard III. Available at www.le.ac.uk/richardiii/ 
Valetas M (2001) The Surnames of Married Women in the European Union. Population and Sociétés No.367, April: 1-4.

Waskul D, Vannini P (2012) Introduction: the Body in Symbolic Interaction'. In: Vannini P, Waskul D (eds) Body/Embodiment: Symbolic Interaction and the Sociology of the Body, pp.118. Aldershot: Ashgate.

West C, and Zimmerman D (1987) Doing Gender. Gender \& Society 1 (2): 125-151

Widner D, Chicoine S (2011) Its All in the Name: Employment Discrimination Against Arab Americans. Sociological Forum 26 (4): 806-803.

Wilson R (2009) A Name of One's Own: Identity, Choice and Performance in Marital Relationships. Unpublished doctoral thesis, Gender Institute of the London School of Economics and Political Science, London.

Wood M Hales J Purdon S Sejersen T and Hayllar O (2009) A Test for Racial Discrimination in Recruitment Practice in British Cities. Department for Work and Pensions, Research Report No 607, London: Her Majesty's Stationery Office.

Wykes E (2015) Invisible Names and Visible Privileges: the Racialisation of Names. Discover Society. Available at http://www.discoversociety.org/2015/03/01/invisible-names

Author biography: Jane Pilcher is Senior Lecturer in Sociology at the University of Leicester, UK. Her publications include Age and Generation in Modern Britain (Oxford University Press), Fifty Key Concepts in Gender Studies (with Imelda Whelehan, Sage) and, most recently, Thatcher's Grandchildren? Politics and Childhood in the Twenty-First Century (coeditor with Stephen Wagg, Palgrave). Jane has also published a series of journal articles on gendered childhoods, focusing on health and sex education and on girls' consumption of 
clothing fashions. Jane has previously written about the sociology of names on her Sociologyblog page, available via janepilcher.me.uk. 